\title{
The Effect of Entrepreneurial Competencies on Innovation: A Case Study of Professional Sport Clubs
}

\author{
Reza Mohammadkazemi ${ }^{1}$, Nazanin Rasekh ${ }^{2}$, Mohammad Navid ${ }^{3}$ \\ ${ }^{1}$ Associate Professor in University of Tehran, Iran \\ ${ }^{2}$ Assistant Professor in Sport Science Research Institute (SSRI), Iran \\ ${ }^{3}$ M.A in entrepreneurship from University of Tehran, Iran \\ Correspondence: Reza Mohammadkazemi, Associate Professor in University of Tehran, Iran. E-mail: \\ r_mkazemi@ut.ac.ir
}

Received: August 17, 2016

Accepted: September 9, 2016

Online Published: September 26, 2016

doi:10.5539/ibr.v9n11p57

URL: http://dx.doi.org/10.5539/ibr.v9n11p57

\begin{abstract}
The aim of the present research is to evaluate the effect of entrepreneurial competencies on innovation in professional sport clubs. In a regression analysis, this paper uses a descriptive correlational field method. The statistical sample population of this research includes the staff and employees from five selected sport clubs, namely: Esteghlal, Perspolis, Naaft-e-Tehran, Sepahan and ZobAhan of Isfahan. For data collection, a standard questionnaire with 65 items was used to evaluate eight competencies: strategic, conceptual, opportunity, relationship, learning, personal, ethical, familyism; and three dimensions of innovation in goods/services, the process and execution. The validity through the convergent validity (AVE $=0.56$ and 0.84 respectively) and the reliability ( 0.95 and $\alpha=0.93 ; 0.91$ and $\mathrm{CR}=0.95$ respectively) were confirmed and were randomly distributed among the statistical sample population. The Smart PLS 2 software and the structural equations modeling (SEM) techniques were used. The obtained results of this research indicate that the there is a positive and significant relationship between the entrepreneurial competencies and innovation $(t=13 / 14$ and $\mathrm{T}$-value $>1 / 96)$. Moreover, there is a positive and significant relationship between all the variables of competencies (i.e. strategic, conceptual, opportunity, relationship, learning, personal, ethical, and familyism) and innovation. The 77\% innovative change as fostered by entrepreneurial competencies is indicative of a strong impact of the entrepreneurial competencies on innovation \& performance of enterprises. Contribution of this paper is measuring these competencies on innovation of professional sport clubs.
\end{abstract}

Keywords: entrepreneurial competencies, innovation, professional sport clubs

\section{Introduction}

Today, with the change in the business environment and the importance of innovation and entrepreneurship in organizations to offer new goods/services and gain competitive advantages, the entrepreneurial competencies have attracted a special attention. The approach to competencies was adopted based on the works of Boyatzis (1982) who define competency as the underlying characteristic that contributes non-permanently to effective or superior job performance (1). From then on, the bulk of research on competencies have increased and extended to different managerial domains. Entrepreneurial competencies involve characteristics and abilities related to the creation of a new, sustainable and growing business. In other words, entrepreneurial competencies refer to the knowledge, skills and behaviors that lead to entrepreneurial ventures or SMEs (2). Based on the definition by the International Consortium for Entrepreneurship Education (ICEE), entrepreneurial competencies entail opportunity recognition, effective relationship with suppliers and customers, relationship with the staff from other businesses for learning and mutual interaction purposes, living in an atmosphere of tolerance for uncertainty, and a series of other competencies related to business growth and development (3). Markman \& et al. introduced self-efficacy and persistence as other entrepreneurial competencies (4). Hayton and Kelly (2006) proposed four types of competencies that engender spin-offs: innovating, brokering, championing, and sponsoring (5). Ahmed \& et al (2010) identified eight domains for entrepreneurial competencies: strategic, conceptual, opportunity, relationship, learning, personal, ethical, and familyism (6).

Given the circumstances today, organizational innovation is highly important for the success and survival of 
firms competition-wise; as innovation acts as a determining element for firms in such conditions. Innovation involves a new or improved way of producing goods/services in a firm to create added value, either directly for the firm itself or indirectly for the customers (7). Various types of innovation have been discussed by different scholars. Studies in the area of innovation have taken into account outputs, inputs, and processes. According to Schumpeter (1934), innovation includes the introduction of new goods/services, development of new methods of production, identification of markets, discovery of new supply sources, and development of new organizational forms (8). In general, innovation has received more attention from researchers in three forms: new products, new processes, or new business systems $(9,10$, and 11). Innovation includes the manufacturing of new products, their improvements, and new methods of production. Ultimately, organizational innovation refers to the promotion of products/services and methods of production. In other words, organizational innovation involves innovation in products and processes where the goal is to introduce change in the systems and procedures of production so that with lower costs and higher productivity it would be possible to manufacture higher quality products. Innovation in products entails the production and introduction of new goods to the market; and it's most important prerequisite is having new and original ideas that can lead to the production of new goods or processes and hence, can be used for achieving higher organizational productivity and efficiency. One way to achieve this, is by providing the essential context that would encourage employees to express ideas and innovate, thus leading the organization or manufacturing company toward organizational innovation. In such organizations, the employees' talents and ideas are the main organizational assets. Implementation of new ideas for organizational renovation, cost-saving, improvement of communications, new technologies for production processes, new organizational structures and new staffing plans are among examples of innovation (12). Innovation, creativity, and change are the key and integral elements in sports (13). Innovation in sports can be defined as the creation of suitable environmental opportunities and the employment of creative and competent employees for seeking out ideas and opinions, which can be later considered in new policymaking decisions and plans that would promote health and athletic drive in the community. In this context, new areas in sports would come about in the country, not to mention the resulting economic benefits that would further help this sector (14). Mugerwa (2013) investigates the relationship between entrepreneurial competencies and firm performance, entrepreneurial competencies and innovation, and innovation and performance among SMEs in Kawempe division, Kampala district. This study results show that there is a meaningful relationship between the research variables. Moreover, the findings suggest a significant and positive relationship between entrepreneurial competencies and firm performance, innovation and firm performance, entrepreneurial competencies and innovation. However, the results from the regression analysis show that the relationship between entrepreneurial competencies and innovation has the potential to account for $39.7 \%$ of variance as a predictor of firm performance. Based on these findings, it is recommended that the owners and managers of SMEs be encouraged to learn about, attain and apply entrepreneurial competencies; because this would lead to an improvement in innovations, hence positive firm performance (15). Sa'ari (2013) examines entrepreneurial competencies and innovative performance in the Academic Libraries of Malaysia. By reviewing the literature, targeted sampling, conducting case studies, and doing multiple interviews, she discovered that the antecedents of entrepreneurial competencies namely, recognizing opportunities, initiating innovation, and strategic thinking influence the innovative performance of libraries (16). In an investigation of the effect of inter- and extra-organizational factors on innovation in professional sport organizations, Smith (2005) showed that the former had a stronger impact (17). Katz (2004) found that three major factors influence the ubiquitous application of innovation: cost, ease of use and reliability and sustainability of methods, processes or technologies. He also found that the application of advanced equipment and employment of expert workforce in sport events or competitions not only increased the satisfaction level of the users and the participants but also facilitated the flow of innovation (18). In an evaluation of technical and technological innovations in sport, Sheridan (2007) concluded that technical innovations (especially in different sport disciplines and in the manners they are introduced) had a more effective role in attracting people to sport than technological innovation. He further suggested that the values and cultural diversity of different communities should be always considered in the introduction of technical and technological innovations along with the structural types and arrangements of the respective sports (19).

Seen as one highly important industry in advanced countries, healthy sport and recreation are an effective factor in the growth and development of national economy. This industry has spread rapidly all over the world benefiting billions of people one way or another. The demand for the globalization of sport began in the 1980s triggering change in the role of sport in the community and creating many revenue opportunities for different people, institutions, and the media. Sport is considered an industry in the world and it is used for attainment of economic goals (20). In Iran, however, sport is still seen as recreation. The latest research indicates that the sport industry contribution to GDP ranges from 0.75 to 4.4 in different countries. This is while the share of this 
industry in the GDP of Iran is a significant 1.1 percent lower than the global index. As increase in any type of investment in the sport sector would mean investment in the health of the community and reduction in treatment costs. Therefore, the provision of the needed facilities to encourage the private sector seems absolutely necessary in this area (21). In light of the changed direction of the country's economic development strategy toward non-oil revenues, the sport industry can serve as a factor for wealth creation. One way to create wealth and stimulate a thriving sport industry includes creativity and innovation. In this paper, we aim to investigate whether entrepreneurial competencies result in promoted and increased innovation in this industry.

\section{Methodology}

The present descriptive study is of the correlational type and utilizes a regression analysis (SEM) and falls into the category of empirical research. As the study variables need to be evaluated and their impact are measured for each outcome, and as the outcomes are to be applicable for a large group of observations, the quantitative approach is adopted for this study. Moreover, as the data were collected at one specific point in time, it is considered a cross-sectional study. The study population includes staff and employees at professional sport clubs. The sample population includes professional soccer clubs namely, Esteqlal, Perspolis, Naft-e-Tehran, Sepahan-e-Esfehan, and Zob Ahan Esfahan. A questionnaire was used as the data collection instrument. In order to evaluate entrepreneurial competencies and innovation, we used the questionnaires developed by Ahmad (2010) (56 items) and Jiménez-Jiménez and Valle (2011) (11 items), respectively $(6,20)$.

The composite reliability and the Cronbach's alpha were used in order to measure reliability and validity. Table 1 presents the composite reliability for each construct of the entrepreneurial competencies and innovation. As all the calculated values are greater than 0.7 , the study has acceptable reliability.

Table 1. Composite reliability and Cronbach's Alpha

\begin{tabular}{|c|c|c|c|c|c|}
\hline Contruct & $\begin{array}{c}\text { Cronbach's } \\
\text { Alpha }\end{array}$ & $\begin{array}{l}\text { Composite } \\
\text { reliability }\end{array}$ & Dimension & $\begin{array}{c}\text { Cronbach's } \\
\text { Alpha }\end{array}$ & $\begin{array}{l}\text { Composite } \\
\text { reliability }\end{array}$ \\
\hline \multirow{8}{*}{$\begin{array}{l}\text { Entrepreneurial } \\
\text { competencies }\end{array}$} & \multirow{8}{*}{$0 / 95$} & \multirow{8}{*}{$0 / 91$} & Strategic & 0.89 & $0 / 92$ \\
\hline & & & Conceptual & $\mathbf{0} / 85$ & $\mathbf{0} / 88$ \\
\hline & & & Opportunity & $\mathbf{0} / 85$ & $\mathbf{0} / 89$ \\
\hline & & & Relationship & $0 / 64$ & $\mathbf{0} / \mathbf{8 1}$ \\
\hline & & & Learning & $0 / 76$ & $\mathbf{0} / \mathbf{8 3}$ \\
\hline & & & Personal & $\mathbf{0} / 88$ & $0 / 90$ \\
\hline & & & Ethical & $0 / 71$ & $\mathbf{0} / \mathbf{8 1}$ \\
\hline & & & Familyism & $0 / 86$ & $0 / 90$ \\
\hline \multirow{3}{*}{ Innovation } & \multirow{3}{*}{$0 / 93$} & \multirow{3}{*}{$0 / 95$} & Goods/services & $\mathbf{0} / \mathbf{8 0}$ & $\mathbf{0} / 88$ \\
\hline & & & Processes & $0 / 91$ & $0 / 94$ \\
\hline & & & Execution & $\mathbf{0} / 87$ & $0 / 92$ \\
\hline
\end{tabular}

The divergent and convergent validity were evaluated to determine the validity of the study. The average variance extracted (AVE) was used as the standard acceptable level (convergent validity greater than 0.5) (22). Based on Table 2, all the AVE values are greater than 0.5 thus confirming the convergent validity.

Table 2. AVE of the variables for the determination of convergent validity

\begin{tabular}{cc}
\hline Variable & AVE \\
\hline Entrepreneurial competencies & $\mathbf{0 / 5 6}$ \\
Strategic & $\mathbf{0 / 5 7}$ \\
Conceptual & $\mathbf{0 / 5 0}$ \\
Opportunity & $\mathbf{0 / 5 8}$ \\
Relationship & $\mathbf{0} / 7 \mathbf{3}$ \\
Learning & $\mathbf{0 / 5 0}$ \\
Personal & $\mathbf{0 / 5 5}$ \\
Ethical & $\mathbf{0 / 5 5}$ \\
Familyism & $\mathbf{0 / 6 5}$ \\
Innovation & $\mathbf{0 / 8 4}$ \\
Good/services & $\mathbf{0 / 7 1}$ \\
Processes & $\mathbf{0} / \mathbf{8 5}$ \\
Execution & $\mathbf{0 / 8 0}$ \\
\hline
\end{tabular}

Divergent validity shows the degree of correlation between one construct and other constructs. Divergent validity is at an acceptable level when the square root of the AVE for a construct is greater than the shared variance between that construct and the other constructs in a given model. As can be seen in Table 3, the square root of the AVE for each construct (the main diagonal elements) is greater than the correlation coefficient of that construct and the other constructs (elements on same rows and same columns). This indicates the acceptability of the divergent validity of the constructs.

Table 3. A comparison matrix of the square roots of AVE values and the correlation coefficients of the constructs 


\begin{tabular}{|c|c|c|c|c|c|c|c|c|c|c|c|}
\hline Dimension & 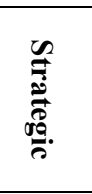 & 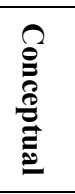 & 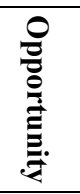 & 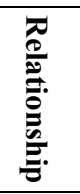 & 离. & $\begin{array}{l}0 \\
0 \\
0 \\
0 \\
0 \\
0\end{array}$ & 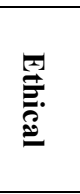 & 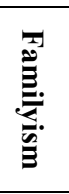 & 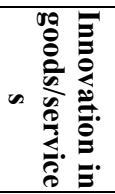 & 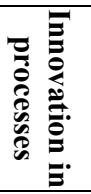 & 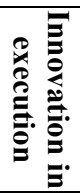 \\
\hline Strategic & $0 / 75$ & & & & & & & & & & \\
\hline Conceptual & $\mathbf{0} / \mathbf{5 5}$ & $\mathbf{0} / 70$ & & & & & & & & & \\
\hline Opportunity & $0 / 43$ & $0 / 67$ & $0 / 76$ & & & & & & & & \\
\hline Relationship & $0 / 49$ & $0 / 68$ & $0 / 56$ & $\mathbf{0} / 85$ & & & & & & & \\
\hline Learning & $\mathbf{0} / \mathbf{3 3}$ & $0 / 64$ & $\mathbf{0} / \mathbf{5 7}$ & $0 / 67$ & $\mathbf{0} / 70$ & & & & & & \\
\hline Personal & $\mathbf{0} / 11$ & $0 / 45$ & $0 / 26$ & $0 / 44$ & $0 / 60$ & $0 / 74$ & & & & & \\
\hline Ethical & 0/52 & $\mathbf{0} / 40$ & 0/41 & $0 / 44$ & $\mathbf{0} / 58$ & 0/41 & 0/74 & & & & \\
\hline Familyism & $0 / 60$ & $0 / 48$ & $\mathbf{0} / 53$ & 0/71 & $0 / 64$ & 0/29 & 0/71 & $\mathbf{0} / \mathbf{8 0}$ & & & \\
\hline Innovation in goods/services & 0/91 & 0/61 & $\mathbf{0} / 50$ & $0 / 60$ & $0 / 49$ & 0/13 & $\mathbf{0} / \mathbf{6 0}$ & $\mathbf{0} / 70$ & 0/84 & & \\
\hline Innovation in processes & $0 / 65$ & $\mathbf{0} / 58$ & $0 / 45$ & $0 / 60$ & $\mathbf{0} / \mathbf{5 2}$ & 0/17 & $\mathbf{0} / 60$ & $0 / 62$ & $\mathbf{0} / 77$ & $0 / 92$ & \\
\hline Innovation in execution & $0 / 635$ & $0 / 47$ & $\mathbf{0} / \mathbf{5 5}$ & $0 / 63$ & $0 / 48$ & $0 / 09$ & $\mathbf{0} / \mathbf{6 3}$ & $0 / 75$ & $0 / 76$ & $0 / 76$ & $0 / 89$ \\
\hline
\end{tabular}

The SPSS 18 software was used in the descriptive analysis section to analyze and test the hypotheses. In the inferential analysis section, the structural equations modeling (SEM) using partial least squares (PLS) was employed to test the research hypotheses using the Smart PLS 2 software.

\section{Research Findings}

In this study, $77 \%$ of the respondents were male and $23 \%$ were female. As regards age, the majority of the respondents $(89 \%)$ were in the $25-35$ and $35-45$ age categories. The remaining $11 \%$ were in the $45-55$ age categories. As regards education, $70 \%$ of the respondents held a bachelor's degree, $21 \%$ a master's degree, $7 \%$ a high school diploma, and $2 \%$ a doctorate's degree. As for work experience, $72 \%$ had over 10 years of experience, $12 \%$ had 5-10 years of experience, $8 \%$ had 3-8 years of experience, and $8 \%$ had less than 3 years of experience. Furthermore, the highest frequency among the fields of study is related to physical education.

The path coefficient $(t)$ of the main model including the entrepreneurial competencies construct as the exogenous variable and the innovation construct as the indigenous construct was used in order to test the main hypothesis.

Based on Figure 2 and Table 4, as the t-statistic is greater than 1.96 at a $95 \%$ confidence level, it can be said that the entrepreneurial competencies have a positive and significant effect on innovation is professional sport clubs. Also, the entrepreneurial competencies account for $77 \%$ of the change in innovation.

Table 4. The main hypothesis of the study

\begin{tabular}{cccc}
\hline Hypothesis & $\begin{array}{c}\text { Path } \\
\text { Coefficient }\end{array}$ & t-statistic & Result \\
\hline $\begin{array}{c}\text { Entrepreneurial competencies have a positive and significant effect } \\
\text { on innovation in professional sport organizations }\end{array}$ & $\mathbf{0 / 7 7 3}$ & $\mathbf{1 3 / 1 4 1}$ & Confirmed \\
\hline
\end{tabular}

Furthermore, based on the obtained data (Table 5), all the eight dimensions of the entrepreneurial competencies have a positive and significant effect on innovation.

Table 5. Analysis of the sub-hypotheses

\begin{tabular}{ccccc}
\hline Independent variable & Dependent variable & Path coefficient & t-statistic & Result \\
\hline Strategic & Innovation & $\mathbf{0} / \mathbf{7 1 2}$ & $\mathbf{7 / 3 2}$ & Confirmed \\
Conceptual & Innovation & $\mathbf{0 / 6 1 2}$ & $\mathbf{7 / 6 1 6}$ & Confirmed \\
Opportunity & Innovation & $\mathbf{0 / 5 5 3}$ & $\mathbf{6 / 0 5 6}$ & Confirmed \\
Relationship & Innovation & $\mathbf{0 / 5 6 7}$ & $\mathbf{6 / 8 0 5}$ & Confirmed \\
Learning & Innovation & $\mathbf{0 / 5 5 9}$ & $\mathbf{7 / 4 3 2}$ & Confirmed \\
Personal & Innovation & $\mathbf{0 / 3 3 4}$ & $\mathbf{3 / 5 6 6}$ & Confirmed \\
Ethical & Innovation & $\mathbf{0 / 7 1 2}$ & $\mathbf{8 / 6 4 1}$ & Confirmed \\
Familyism & Innovation & $\mathbf{0 / 7 5 7}$ & $\mathbf{1 1 / 0 5 4}$ & Confirmed \\
\hline
\end{tabular}




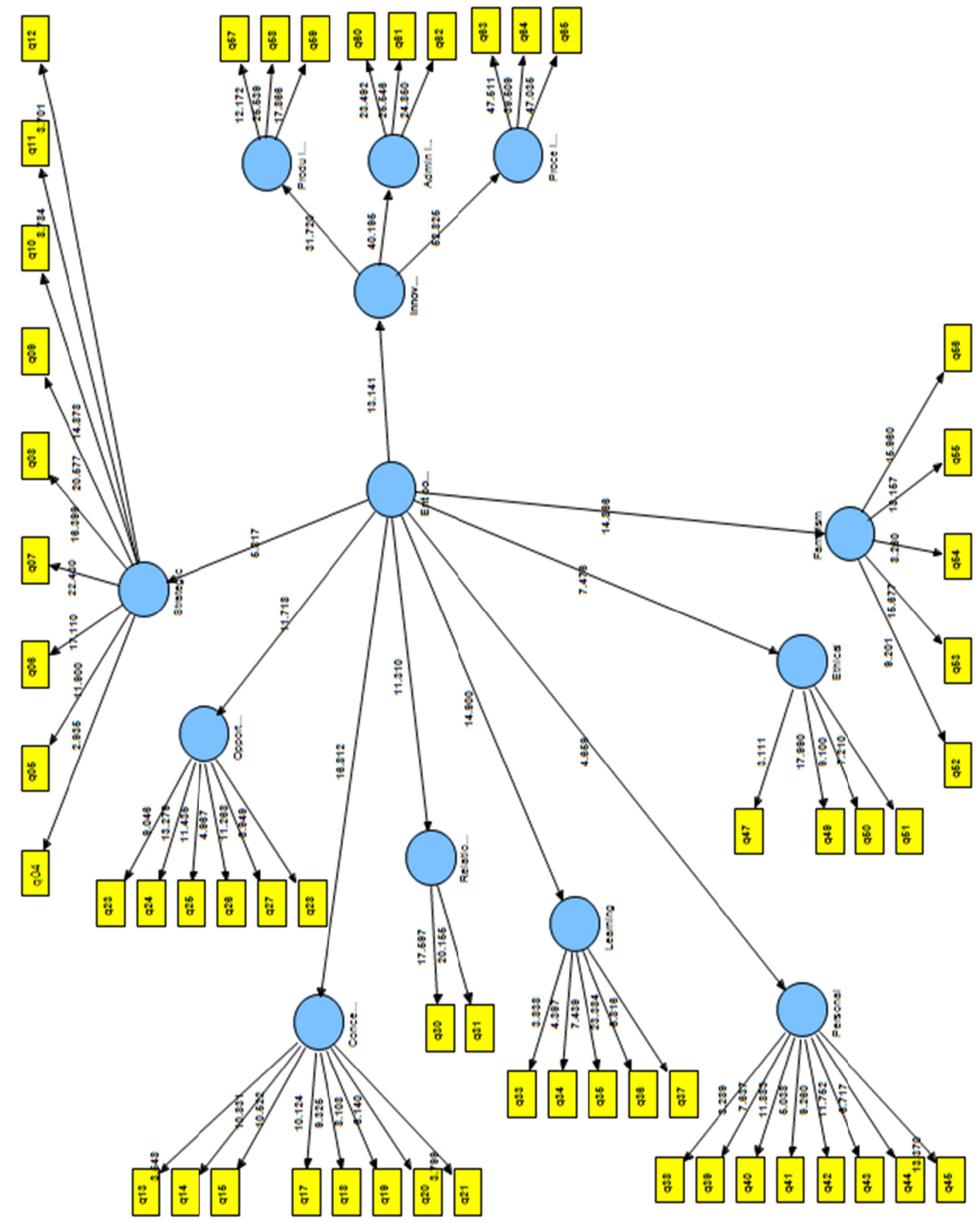

Figure 1. The meaningfulness coefficients for the main study hypothesis

\section{Discussion and Conclusion}

The aim of this paper is to evaluate the effect of entrepreneurial competencies on innovation in professional sport clubs. The results showed that there is a positive and significant relationship between entrepreneurial competencies and innovation. Consistent with our results are studies by Mugerwa (2013) and Sa'ari (2013) which reported a positive and meaningful relationship between entrepreneurial competencies and innovation (15 \& 16). The study results concerning the sub-hypotheses suggest that there is a positive and significant relationship between the strategic competency and innovation. Researches by Miles (1987) \& Kordnayyj (2002) showed that an innovative organization utilizes the aggressive strategy in a dynamic environment (23). The ability to predict the future, understand the environment, and effective planning for future attainments are all contingent upon strategic thinking. Moreover, in the competitive environment of survival and growth, firms need 
to have competitive advantage and a strategic approach allows the firm to gain competitive advantage. In light of these studies it can be concluded that strategy is among the effective elements that foster innovation. Innovative strategies can help firms and industries understand how and where they can adopt innovation in order to promote or improve their performance. It was found in this study that there is a positive and significant relationship between the conceptual competency and innovation. Based on the concept of conceptual competency, it is clear that it is essential to study and survey new ideas, take risks, and understand business concepts, etc. in order to foster innovation. The results indicate a positive and significant relationship between the opportunity competency and innovation. In his famous book "Innovation and Entrepreneurship", Peter Drucker (1986) lists seven sources of innovative opportunity (the unexpected, incongruities, process needs, industry and market structure change, demographics, changes in perception, meaning, and mood, and new knowledge) (24). The positive and meaningful relationship between the relationship competency and innovation shows that relationship is among the most important elements for business success in dynamic and constantly changing environments. The studies by Ramani and Kumar (2008) and Panayides (2006) suggest that customer relationship management (CRM) is one of the important elements for the development of the innovation capability ( $25 \& 26)$. The positive and significant relationship between the learning competency and innovation indicates that organizational learning provides a context and the requirements for occurrence of innovation, hence improved performance and competitive advantages. Alberto et al. (2007) also found a significant relationship between organizational learning and innovation (27). A study results show that there is a positive and significant relationship between personal competency and innovation. According to Lawler (1973), innovative performance in individuals is decided by their abilities and levels of skill (28). Motivation is one of the major and effective factors that influence innovation. Sternberg (1999) argues that intrinsic motivations are more important for creative activities to occur than extrinsic motivations (29). In every innovative process and every new venture creation, work ethics enhance and facilitate the efforts and progress. Organizations have realized that through promoting work ethics and morality they can provide a context for innovation and entrepreneurship in the organization. This is also supported by the positive and significant relationship between the personal competency and innovation in this study. The findings from the last hypothesis show that there is a significant and positive relationship between familyism and innovation. The previous literature about familyism competency shows that this variable influences business success (one of the outcomes of innovation) (30). Furthermore, knowledge sharing (one of the dimensions and instances of the familyism competency) has a positive and significant relationship with innovation (31) and is essential for improving innovation (32).

Based on the above, the following is recommended for sport club's manager:

According to the main hypothesis and based on the fact that $77 \%$ of change in innovation is accounted for by entrepreneurial competencies, it seems that if sport organizations managers seek innovation and hence new venture creation and profit-making, they ought to pay special attention to entrepreneurial competencies. This is because innovation is the result of creative thinking, creative ideas, and a creative mindset and its achievement requires skill and competencies.

As $71 \%$ of change in innovation is accounted for by the strategic competency, it seems that innovation is greatly influenced the strategic competency. Clearly, an integrated strategic management in sport organizations that develops and oversees the implementation and advancement of strategies can help them improve their strategic competency, and therefore accomplish innovation, venture creation and competitive advantages.

Opportunity is one the key components of the entrepreneurial process and one of the main survival and success factors. Considering market needs, customer needs (i.e. fans) and seeking to exploit highly productive opportunities, sport organizations could enhance their opportunity competency and thus grasp innovative opportunities.

\section{Suggestions for Future Researches}

Learning supports creativity, news ideas, and new knowledge and improves the ability to understand and exploit them. Innovation becomes possible by obtaining knowledge from different sources and then applying them. By holding in-service training courses, sport organizations could improve learning among their employees. Moreover, the learning competency could be improved by employing knowledgeable individuals. So it is recommended for future researchers to do this method on their employees too.

Among the entrepreneurial competencies, familyism has the most effect on innovation suggesting that it has a good place in sport organizations. However, by adopting solutions such as creating consulting databases through partnerships, this competency can be further improved. So it is recommended for future researchers to do this method by focusing on familyism too. 


\section{References}

Ahmad, N. H., Ramayah, T., Wilson, C., \& Kummerow, L. (2010). Is entrepreneurial competency and business success relationship contingent upon business environment? A study of Malaysian SMEs. International Journal of Entrepreneurial Behavior \& Research, 16(3), 182-203. http://dx.doi.org/10.1108/13552551011042780

Ahmad, N., Kummerow, L., \& Wilson, C. (2006). A cross-cultural study of entrepreneurial competencies among business owners in SMEs: evidence from Australia and Malaysia. Paper presented at the 51st ICSB World Conference, Melbourne.

Alberto, J., Arango, C., Victor, J. G. M., \& Eulogio, C. P. (2007). Leadership and organizational learning's role on innovation and performance: Lessons From Spain. Industrial Marketing Management, 36, 349-359. http://dx.doi.org/10.1016/j.indmarman.2005.09.006

Bird, B. (1995). Toward a theory of entrepreneurial competency. Advances in entrepreneurship, firm emergence and Growth, 2, 51-72.

Boyatzis, R. E. (1982). The Competent Manager: A Model For Effective Performance. New York: Wiley.

Business Council of Australia. (1993). Managing the Innovating Enterprise. Melbourne, BCA.

Crespell, P., \& Hansen, E. (2007). Work climate and innovativeness in the forest products industry: a preliminary approach. Submitted to Journal of Forest Products Business Research.

Drucker, P. (2013). Innovation and Entrepreneurship. Trans. Ali Hossein Keshavariz. $1^{\text {st }}$ ed, Samt Publications, Tehran.

Fornell, C., \& Larcker, D. F. (1981). Evaluating Structural Equation Models with Unobservable Variables and Measurement Error. Journal of Marketing Research, 18(1), 39-50. http://dx.doi.org/10.2307/3151312

Hadizadeh, M. A., Mohebbi, P., \& Qelich, L. B. (2012). An investigation of the relationship between knowledge sharing and innovation in financial service organizations: Refah-e-Kargaran Bank. Management Research in Iran, 17(1), 201-220.

Hayton, J. C., \& Kelly, D. (2006). A Competency-Based Framework for Promoting Corporate Entrepreneurship. Human Resource Management Journal, 45(3), 407-427. http://dx.doi.org/10.1002/hrm.20118

Hovgaard, A., \& Hansen, E. (2004). Innovativeness in the forest products industry. Forest Products Journal, 54(1), 26-33.

Jiménez, J. D., \& Valle, R. S. (2011), Innovation, organizational learning, \& performance. Journal of Business Research, 64(4), 408-417. http://dx.doi.org/10.1016/j.jbusres.2010.09.010

Katz, D. M. (2004). Innovation in Sport as Functional Concept for Future. Journal of Sport Psychological, 4, 43-65.

Knowles, C., Hansen, E., \& Shook, S. (2007). Assessing innovativeness in the North American softwood sawmilling industry using three methods. Canadian Journal of Forest Research (in review).

Lawler, E. E. (1973). Motivation in Work Organizations. Monterey CA: Brooks/Cole.

Markman, G. D., Baron, R. A., \& Balkin, D. B. (2005). Are perseverance and self-efficacy costless? Assessing entrepreneurs' regretful thinking. Journal of Organizational Behavior, 26(1), 1-19. http://dx.doi.org/10.1002/job.305

Martins, E. C., \& Terblanche, F. (2003). Building Organizational Culture that Stimulates Creativity and Innovation. European Journal of Innovation Management, 6(1), 64-74. http://dx.doi.org/10.1108/14601060310456337

Miles, R. E., \& Charles, C. (1987). Organizational Sterategy, Structure, and Process. New York: McGraw-Hill.

Mohammad, K. R. (2015). Sports Marketing and Social Media. In N. Hajli (Ed.), Handbook of Research on Integrating Social Media into Strategic Marketing (pp. 340-358). Hershey, PA: Business Science Reference.

Mohammad, K. R., \& Omidi, Y. (2011). Sport Entrepreneurship: An emerging approach toward entrepreneurship and sport management. Biannual Journal of Sport Management and Motor Behavior Research (In Persian), 2, 69-87.

Mohammmadkazemi, R. T. F., Heydar, S., \& Darvish, M. (2014). Football refereeing: Identifying innovative methods. Journal of Management Science Letters, 4, 1707-1714. http://dx.doi.org/10.5267/j.msl.2014.7.013 
Mugerwa, E. A. (2013). Entrepreneurial competencies, innovation and firm performance: a case of SMEs in Kawempe division Kampala district. Masters dissertation, Makerere University, Kampala, Uganda.

Onstenk, J. (2003). Entrepreneurship and Vocational Education. European Educational Research Journal, 2(1), 74-89. http://dx.doi.org/10.2304/eerj.2003.2.1.12

Panayides, P. (2006). Enhancing innovation capability through relationship management and implications for performance. European Journal of Innovation Management, 9(4), 466-483. http://dx.doi.org/10.1108/14601060610707876

Ramani, G., \& Kumar, V. (2008). Interaction Orientation and Firm Performance. Journal of Marketing, 72(1), 27-45. http://dx.doi.org/10.1509/jmkg.72.1.27

Sa'enz, J., \& Rivera O. (2009). Knowledge sharing and innovation performance. Journal of Intellectual Capital, 10(1), 22-36. http://dx.doi.org/10.1108/14691930910922879

Sa'ari, H. (2013). Identifying Entrepreneurial Competencies Which Lead To Innovative Performance in Malaysian Academic Libraries. Paper read at 4th International Conference on Information Management and Evaluation (ICIME) in Ho Chi Min City, Vietnam on 13-14 May.

Schumpeter, J. A. (1934). The theory of economic development: An inquiry in to profits, capital credit, Interest and the business cycle .Cambridge: Harvard Business Press.

Sheridan, H. (2007). Evaluating Technical and Technological Innovations in Sport. Journal of Sport and Social Issues, 31(2), 179. http://dx.doi.org/10.1177/0193723507300485

Smith, H. (2005). Influence of Inter- Organizational and Extra- Organizational Factors on Innovation in PSL. Journal of Sport Management, 15, 135-159.

Sternberg, R., \& Lubart, T. (1999). The Concept of creativity: Prospects and paradigms. In R. Sternberg (Ed.), Handbook of creativity. Cambridge University press.

\section{Copyrights}

Copyright for this article is retained by the author(s), with first publication rights granted to the journal.

This is an open-access article distributed under the terms and conditions of the Creative Commons Attribution license (http://creativecommons.org/licenses/by/4.0/). 